\title{
A new genus and species of pinworm (Nematoda, Oxyuridae) from the gray mouse opossum, Tlacuatzin canescens
}

\author{
F. Agustín Jiménez ${ }^{1, *}$, Juan Manuel Caspeta-Mandujano², and Sergio Albino-Miranda ${ }^{3}$ \\ ${ }^{1}$ Department of Zoology, Southern Illinois University, Carbondale, IL 62901-6501, USA \\ ${ }^{2}$ Laboratorio de Parasitología de Animales Silvestres, Facultad de Ciencias Biológicas, Universidad Autónoma del Estado de Morelos, \\ Av. Universidad No. 1001, Col. Chamilpa, CP 62210 Cuernavaca, Morelos, México \\ ${ }^{3}$ Red de Biología y Conservación de Vertebrados, Instituto de Ecología A. C., Carretera Antigua a Coatepec 351, El Haya, Xalapa 91070 , \\ Veracruz, México
}

Received 30 May 2019, Accepted 6 August 2019, Published online 21 August 2019

\begin{abstract}
Tlacuatzoxyuris simpsoni n. gen. n. sp. is described from the cecum of the gray opossum, Tlacuatzin canescens, a species endemic to the deciduous dry forest of Mexico. The digestive tracts of four specimens were examined for parasites; three of these were archived in the American Museum of Natural History and one was a live capture. Relative to the other four monotypic genera of pinworms known to infect opossums, the new genus is diagnosed on the basis of a round cephalic plate with a semicircular stoma surrounded by a rim. In addition, males feature a prominent cephalic vesicle not fully developed in females, accounting for sexual dimorphism. The new species includes small worms that feature a conspicuous, not reticulated cephalic vesicle and semicircular stoma and lateral alae with two crests. In addition, the postcloacal cuticle of males features a small area with ornamentation between cloaca and submedial papillae. Finally, both spicule and gubernaculum are relatively short. Although the eggs of Tlacuatzoxyuris n. gen. are unknown, the conspicuous differences in traits used in the diagnosis of genera prompted us to propose a new genus for the new species. This is the first species of Oxyuridae reported in mouse opossums outside South America, and the fifth species of the family occurring in didelphimorph marsupials. This is an example of the usefulness of documenting the diversity of parasites associated with this unique clade of mammals through the examination of preserved tissues.
\end{abstract}

Key words: Tlacuatzoxyuris simpsoni, Tlacuatzin canescens, Great American Biotic Interchange, Endemism, Oxyuridae, Scientific collections.

\begin{abstract}
Résumé - Un nouveau genre et une nouvelle espèce d'oxyure (Nematoda, Oxyuridae) parasite de l'opossumsouris gris Tlacuatzin canescens. Tlacuatzoxyuris simpsoni n. gen. n. sp. est décrit à partir du caecum de l'opossum-souris gris Tlacuatzin canescens, une espèce endémique de la forêt sèche à feuilles caduques du Mexique. Les appareils digestifs de quatre spécimens ont été examinés pour rechercher des parasites ; trois d'entre eux étaient archivés au Musée Américain d'Histoire Naturelle et un provenait de capture. Par rapport aux quatre autres genres monotypiques d'oxyures connus pour infecter les opossums, le nouveau genre est diagnostiqué sur la base d'une plaque céphalique ronde avec une stomie semi-circulaire entourée d'un rebord. De plus, les mâles présentent une vésicule céphalique importante non développée chez les femelles, ce qui explique le dimorphisme sexuel. La nouvelle espèce comprend des vers petits, présentant une vésicule céphalique bien visible, non réticulée, une stomie semi-circulaire et des ailes latérales avec deux crêtes. En outre, la cuticule postcloacale des mâles présente une petite zone ornementée entre le cloaque et les papilles sous-médiales. Enfin, le spicule et le gubernaculum sont relativement courts. Bien que les œufs de Tlacuatzoxyuris n. gen. soient inconnus, les différences marquées dans les traits utilisés dans le diagnostic des genres nous ont incités à proposer un nouveau genre pour la nouvelle espèce. Il s'agit de la première espèce d'Oxyuridae signalée chez les opossums-souris en dehors de l'Amérique du Sud et de la cinquième espèce de la famille chez des marsupiaux didelphimorphes. Ceci est un exemple de l'utilité de documenter la diversité des parasites associés à ce clade unique de mammifères grâce à l'examen de tissus préservés.
\end{abstract}

\section{Introduction}

Marsupials are a typical component of the Neotropics $[28,30,31]$. In the Americas, this group of mammals

*Corresponding author: agustinjz@zoology.siu.edu includes three families in three orders of which Didelphidae (Didelphimorphia: Didelphidae) contains roughly 110 species of small to medium-sized marsupials [11, 23, 27, 32]. These diversified into arboreal, scansorial, terrestrial, and semiaquatic habits [4]. The continuous investigation of the basic biology,

This is an Open Access article distributed under the terms of the Creative Commons Attribution License (http://creativecommons.org/licenses/by/4.0), which permits unrestricted use, distribution, and reproduction in any medium, provided the original work is properly cited. 
Table 1. Information on gray mouse opossums and Mexican mouse opossums examined for pinworms. Specimens were collected in Oaxaca, Mexico and accessioned in the American Museum of Natural History, New York, NY.

\begin{tabular}{|c|c|c|c|c|c|c|c|}
\hline Col. No. & $\begin{array}{l}\text { Species } \\
\text { name }\end{array}$ & Municipality & Locality name & Collector & Date & Sex & $\begin{array}{l}\text { Pinworm } \\
\text { infection }\end{array}$ \\
\hline M-144638 & $\begin{array}{l}\text { Tlacuatzin } \\
\text { canescens }\end{array}$ & Tehuantepec & Salazar & $\begin{array}{l}\text { Thomas B. } \\
\text { MacDougall }\end{array}$ & $27-F e b-46$ & Male & Negative \\
\hline M-165652 & $\begin{array}{l}\text { Tlacuatzin } \\
\text { canescens }\end{array}$ & Tehuantepec & Las Tejas & $\begin{array}{l}\text { Thomas B. } \\
\text { MacDougall }\end{array}$ & 20-Aug-50 & Male & 1 male \\
\hline M-165653 & $\begin{array}{l}\text { Tlacuatzin } \\
\text { canescens }\end{array}$ & Tehuantepec & Las Tejas & $\begin{array}{l}\text { Thomas B. } \\
\text { MacDougall }\end{array}$ & 11-May-51 & Male & Negative \\
\hline M-189482 & $\begin{array}{l}\text { Marmosa } \\
\quad \text { mexicana }\end{array}$ & Pochutla & $\begin{array}{l}2 \text { miles east of San } \\
\text { Gabriel Mixtepec }\end{array}$ & A. L. Tuttle & 25-Jul-62 & Male & Negative \\
\hline M-213651 & $\begin{array}{l}\text { Marmosa } \\
\text { mexicana }\end{array}$ & Ixtlan & $\begin{array}{l}\text { Santiago Comaltepec, } \\
\text { Vista Hermosa }\end{array}$ & $\begin{array}{l}\text { Thomas B. } \\
\text { MacDougall }\end{array}$ & $\begin{array}{l}\text { Not } \\
\text { Available }\end{array}$ & Sex Unknown & Negative \\
\hline M-232547 & $\begin{array}{l}\text { Marmosa } \\
\text { mexicana }\end{array}$ & Ixtlan & $\begin{array}{l}\text { Santiago Comaltepec, } \\
\text { Vista Hermosa }\end{array}$ & $\begin{array}{l}\text { Thomas B. } \\
\text { MacDougall }\end{array}$ & 27-Mar-69 & Sex Unknown & Negative \\
\hline
\end{tabular}

distribution and diversity of these marsupials has allowed researchers to document the isolation of some populations, to establish the geographic and taxonomic limits for several genera, and to generate evidence to formally describe new didelphimorph taxa [3, 14, 16, 29].

Perhaps because of their ubiquitous nature and high abundance, most helminthological records are centered in four species of medium-sized opossums [1, 19, 25], yet very few helminth taxa had been described from small sized marsupials of arboreal habitats [2, 5, 7, 9, 13, 17, 18, 20, 22, 24]. Among those, four monotypic genera of nematodes infecting arboreal and terrestrial mouse opossums have been described in South America. These include Neohilgertia venusti Navone, Suriano \& Pujol, 1990, from Thylamys venustus; Didelphoxyuris thylamisis Gardner \& Hugot, 1995 from Thylamys elegans and Thylamys venustus; Monodelphoxyuris dollmeiri Guerrero \& Hugot, 2003 from Monodelphis emiliae, and Gracilioxyuris agilisis Feijó, Torres, Maldonado \& Lanfredi, 2008 from Gracilinanus agilis and Marmosa paraguayana [8, 12, $15,21]$. Most of these species are characterized by their relatively short tail and by the presence of numerous mamelons on the ventral side. The criteria to differentiate each of these monotypic genera include the configuration of the stoma or buccal opening, presence of a cephalic vesicle, as well as the ornamentation of the egg shell. The stoma in the four known species is an important element in the diagnosis of these taxa; it can be surrounded by three "lips", which cover 3-4 pharyngeal teeth. The cephalic vesicle is either absent, or thick, with conspicuous internal vesicles in the females of $D$. thylamisis. Finally, the eggs have been characterized as either operculated or nonoperculated, and the eggs of G. agilisis feature three longitudinal ridges which are used in the diagnosis of the genus.

Herein, we describe a new species of pinworm found in the large intestine of the gray opossum, Tlacuatzin canescens (Allen, 1893) in the dry forest of southern Mexico. Since it shows clear differences in the configuration of the cephalic vesicle and the stoma with the other four monotypic genera, we propose a new genus to include it. This is the fifth oxyurid species identified in didelphid marsupials and the first one occurring north of the basin of the Amazon river. The finding of this nematode in a marsupial north of the Panama isthmus has implications relative to the dispersal of fauna of South
American origin into the North American tectonic plate, which is part of the reciprocal biotic exchange among the two landmasses of the New World known as the Great American Biotic Interchange.

\section{Materials and methods}

A single gray mouse opossum was hand trapped in the locality of Cruz Pintada: Morelos: Mexico $\left(18^{\circ} 27^{\prime} 58^{\prime \prime} \mathrm{N}, 99^{\circ}\right.$ $2^{\prime} 16^{\prime \prime} \mathrm{W}, 1016 \mathrm{~m}$ ) on 10 June 2010 . The individual was humanely euthanized and examined for parasites $12 \mathrm{~h}$ after trapping, following methods approved by the Institutional Animal Care and Use protocol 09-026 (Assurance Number A-3078-01). Specimens resulting from this examination were fixed in $4 \%$ buffered formaldehyde and subsequently transferred to $70 \%$ ethanol for storage. In addition, the digestive tracts of three gray opossums and three Mexican mouse opossums (Marmosa mexicana Merriam, 1897) collected in the isthmus of Tehuantepec were requested from the American Museum of Natural History (AMNH) (New York, NY). These tissues were rinsed and cut open, all removed metazoans were washed and saved in $70 \%$ ethanol. Collection numbers and locations for these specimens are detailed in Table 1. All 15 pinworms found were cleared in temporary mounts of lactophenol or glycerine. All measurements are given in micrometers and detailed in Table 2; for each character, the range is given first, followed by mean and coefficient of variation [26]. After clearing, two specimens, a male and a female, were washed and then dehydrated progressively in a graded ethanol series, dried to a non-liquid state by critical point drying using $\mathrm{CO}_{2}$, attached to an SEM stub, and sputter coated with gold palladium. Specimens imaged with SEM were exposed to a beam of $2-10 \mathrm{kV}$ on a FEI Quanta 450 Field Emission Scanning Electron Microscope (FEI, Hillsboro, Oregon). Specimens of D. thylamisis Gardner \& Hugot, 1995; Monodelphoxyuris dollmeiri Hugot \& Guerrero, 2003, and Neohilgertia venusti Navone, Suriano \& Pujol, 1990 were borrowed from the Harold W. Manter Laboratory of Parasitology (HWML, Lincoln, Nebraska); type specimens were deposited in the Colección Nacional de Helmintos (CNHE), of the Universidad Nacional Autónoma de México, México City. A single male collected from the examination of 
Table 2. Measurements of type specimens used in the characterization and description of Tlacuatzoxyuris simpsoni, parasite of the gray opossum Tlacuatzin canescens (Allen, 1893) endemic to Mexico. Specimens were collected in the locality of Cruz Pintada, Morelos (18 $\left.27^{\prime} 58^{\prime \prime} \mathrm{N}, 99^{\circ} 2^{\prime} 16^{\prime \prime} \mathrm{W}, 1016 \mathrm{~m}\right)$, with the exception of AMNH IZC 331457 , Tlacuatzoxyuris sp., from Las Tejas: Oaxaca $\left(16^{\circ} 21^{\prime} 3.69^{\prime \prime} \mathrm{N}, 95^{\circ} 20^{\prime} 3.86^{\prime \prime} \mathrm{W}, 117 \mathrm{~m}\right)$.

\begin{tabular}{|c|c|c|c|c|c|c|c|c|c|c|c|c|c|c|c|}
\hline Specimen & Allotype & Female 1 & Female 3 & Female 4 & Female 5 & Female 6 & Female 7 & Female 8 & Female 9 & Holotype & Male 2 & Male 3 & Male 4 & Male 5 & $\begin{array}{c}\text { AMNH IZC } \\
331457\end{array}$ \\
\hline Body length & 2630 & 2427 & 2416 & 1715 & 1721 & 1452 & 1608 & 1619 & 1548 & 1477 & 1229 & & 1216 & 1294 & 1023 \\
\hline Maximum width & 163 & 170 & 201 & 123 & 138 & 131 & 138 & 111 & 194 & 155 & 107 & & 113 & 145 & 130 \\
\hline Cephalic vesicle length & 0 & 124 & 113 & 109 & 106 & 102 & 101 & & 94 & 94 & 79 & 73 & 89 & 84 & 70 \\
\hline Cephalic vesicle width & 68 & 69 & 61 & 59 & 66 & 59 & 58 & & 60 & 65 & 50 & 55 & 54 & 63 & 49 \\
\hline Depth of stoma & 5 & 8 & 5 & 9 & 6 & 8 & 7 & & 6 & - & 9 & 7 & 7 & 7 & 3 \\
\hline Pharynx & - & - & - & - & - & - & 4 & 8 & 10 & - & 11 & 13 & 8 & 11 & 9 \\
\hline Pharynx width & - & - & - & - & - & - & - & 12 & 10 & - & 14 & 16 & 11 & 13 & 23 \\
\hline Esophagus length & 256 & 250 & 251 & 220 & 225 & 216 & 231 & 237 & 220 & - & 186 & 196 & 175 & 189 & 179 \\
\hline \multirow{2}{*}{ Isthmus } & 13 & 10 & 10 & 13 & 13 & 16 & 16 & 20 & 11 & - & 13 & 9 & 11 & 11 & 9 \\
\hline & & & 25 & 16 & 18 & 15 & 16 & 14 & 14 & - & 14 & 14 & 14 & 14 & 13 \\
\hline Corpus length & 176 & 157 & 159 & 138 & 138 & 129 & 156 & 155 & 122 & - & 109 & 130 & 110 & 123 & 120 \\
\hline Corpus width & 44 & 41 & 43 & 33 & 33 & 29 & 28 & 29 & 30 & - & 27 & 29 & 25 & 28 & 29 \\
\hline Bulb length & 69 & 70 & 71 & 60 & 63 & 57 & 56 & 57 & 64 & - & 52 & 56 & 46 & 49 & 53 \\
\hline Bulb width & 70 & 72 & 69 & 56 & 56 & 51 & 49 & 48 & 55 & - & 45 & 46 & 44 & 46 & 48 \\
\hline \multicolumn{16}{|l|}{ Distance anterior end to: } \\
\hline Nerve ring & 91 & 106 & 112 & 98 & 100 & 83 & 91 & 85 & 86 & 102 & 87 & 89 & 89 & 73 & 89 \\
\hline Excretory pore & 504 & 452 & 480 & 351 & 337 & 322 & 341 & 469 & & 418 & & & 324 & 342 & 286 \\
\hline Vulva & 591 & 538 & 594 & 428 & 425 & 388 & 411 & 505 & 405 & & & & & & \\
\hline Testis & & & & & & & & & & 570 & & & 472 & 474 & 280 \\
\hline Start area rugosa & & & & & & & & & & 718 & 710 & & 629 & 569 & 537 \\
\hline Spicule length & & & & & & & & & & 90 & 88 & 84 & 81 & 88 & 65 \\
\hline Spicule width & & & & & & & & & & 5 & 6 & 5 & 6 & 5 & \\
\hline \multirow[t]{2}{*}{ Gubernaculum } & & & & & & & & & & 35 & 50 & 42 & 45 & 35 & 44 \\
\hline & & & & & & & & & & 5 & 4 & 4 & 5 & 4 & 5 \\
\hline Ovejector & 87 & 86 & - & - & - & - & - & - & - & & & & & & \\
\hline Post anal/cloacal terminus & 166 & 348 & 415 & 363 & 372 & 245 & 271 & 347 & 413 & 52 & 46 & 45 & 42 & 45 & 31 \\
\hline
\end{tabular}


fluid preserved guts was deposited in the invertebrate collection of the AMNH.

\section{Results}

\section{Tlacuatzoxyuris n. gen.}

\section{urn:lsid:zoobank.org:act:98673C5B-786D-4761-A6CE-} 87B1C2ECC83B

Type species: Tlacuatzoxyuris simpsoni $\mathrm{n}$. sp.

Etymology: The genus name is a combination of the Nahuatl word Tlacuatzin, meaning opossum, and the composition oxyuris from the Greek words oxys, sharp and oura, tail.

General: Oxyuridae. Small worms, whitish when alive. Round cephalic plate, semicircular stoma, in terminal depression, surrounded by rim. Lateral alae emerge from cephalic vesicle and runs to tip of tail; alae show two crests.

Male: Prominent, round cephalic vesicle in males. Keel-like area rugosa present, with transverse striations. Four pairs of caudal papillae, two pairs adanal, one pair submedial, posterior to cloaca, one pair terminal. Rough cuticular plate immediately posterior to cloaca. Phasmids oriented dorsally. Spicule and gubernaculum present. Non-salient terminus.

Female: Cephalic cuticle excretory pore and vulva in anterior third of body; thick muscular vagina; didelphic.

\section{Tlacuatzoxyuris simpsoni $\mathrm{n} . \mathbf{s p}$.}

urn:lsid:zoobank.org:act:2FA1FAC2-7A61-4E71-BBAC-

\section{B8072F07D2A0}

(Figs. 1-12)

Type host: Tlacuatzin canescens (Allen, 1893).

Symbiotype: Universidad Autónoma de Morelos, Centro de Investigaciones Biológicas, Cuernavaca, Morelos (UAEM no number).

Type locality: Cruz Pintada: Morelos: Mexico $\left(18^{\circ} 27^{\prime} 58^{\prime \prime} \mathrm{N}\right.$, $\left.99^{\circ} 2^{\prime} 16^{\prime \prime} \mathrm{W}, 1016 \mathrm{~m}\right)$.

Date of collection of type specimens: 10 June 2010.

Type-specimens deposited: Holotype, male CNHE8347. Allotype, female CNHE8348; paratypes CNHE8349.

Site of Infection: Large intestine.

Etymology: The species is named after George Gaylord Simpson, American paleontologist who specialized in the study of mammalian evolution. His investigations on the Paleocene fossils from North America, as well as the Neogene fossils of Florida and Patagonia allowed him to formulate the mammalian transitions of the Great American Biotic Interchange.

General: Small worms, whitish when alive; round cephalic vesicle, simple; body width gradually increasing posterior to cephalic vesicle, reaching maximum at midbody, and tapering towards posterior end. Round cephalic plate with four submedial papillae and lateral amphids (Fig. 1). Stoma semicircular, in terminal depression, surrounded by rim (Figs. 1 and 8). Esophagus endowed with three esophageal teeth (Figs. 1 and 8). Lateral alae emerge from cephalic vesicle and runs to tip of tail; alae taper at level of cloaca and anus in males and females, respectively. Alae show two crests (Fig. 4).
Males (based on five types, unless otherwise noted): Small fusiform worms, length 1216-1477, $1304(9 \%, n=4)$ with both ends truncated (Fig. 3), maximum width at midbody 107-155, $130(18 \%, n=4)$. Cephalic vesicle 73-94, $84(10 \%)$ long by 50-65, 57 (11\%) wide. Well-developed lateral alae with two crests (Fig. 4), crests fuse into one at both ends; alae begin at level of nerve ring and ends anterior to cloaca. Esophagus length $175-196,186(5 \%, n=4)$; corpus length 109-130, $118(9 \%, n=4)$, width 25-29, $27(7 \%, n=4)$; bulb length $46-56,51(8 \%, n=4)$, width $44-46,45(2 \%, n=4)$. Nerve ring, excretory pore and area rugosa located at 73-102, 88 (12\%), 324-418, $361(14 \%, n=3)$, and 569-718, $656(11 \%$, $n=4)$ respectively from anterior end (Fig. 3). Continuous ventral area rugosa appears divided into 5-7 narrow mamelons (Fig. 3). Round postanal region 42-52, 46 (8\%) long and 46-50, 48 (3\%) wide (Figs. 2, 5, 6); distal end serves as basis for terminal papillae (Figs. 2, 5, 6). Non-salient terminus 28-38, $33(13 \%)$ long (Figs. 5 and 6). Four pairs of genital papillae; two pairs sublateral, immediately anterior to cloaca; one pair subventral, postcloacal, and one pair subterminal, pedunculated (Figs. 2 and 6). Postcloacal ornamentation in narrow area between cloaca and subventral papillae (Fig. 2). Phasmids emerge from the peduncle of terminal papillae towards dorsal side (Figs. 5 and 6). Monorchid. Spicule with moderate inflection, length 81-90, 86 (4\%), width at calamus 5-6, 5 (11\%). Gubernaculum 35-50, 41 (16\%) long, 4-5, 4 (8\%) wide (Figs. 5 and 6).

Females (based on nine types, unless otherwise noted): Fusiform worms, length 1452-2630, 1904 (24\%), maximum width at midbody 111-201, 152 (21\%) (Fig. 7). Cephalic vesicle $94-124,107(9 \%, n=4)$ long by $56-69,62(7 \%, n=4)$ wide. Lateral alae emerge from cephalic vesicle, runs continuously to tail end; two crests at level of vulva, midbody and rectum (Figs. 10-12). Esophagus length 216-256, 234 (7\%); corpus length 122-176, 148 (12\%), width 28-44, 35 (19\%); bulb length 56-71, 64 (9\%), width 48-72, 58 (16\%) (Fig. 9). Nerve ring, excretory pore and vulva located 83-112, 95 (11\%); 322-504, 407 (19\%) and 388-594, 476 (17\%) respectively from anterior end (Fig. 7). Vulva connected to muscular ovejector, ovejector to short vestibule and this to two uterine branches (prodelphic). Muscular ovejector 74-87, 82 (9\%) long (Fig. 7). Tail tapers to a point, 165-415, 326 (25\%) long (Fig. 7). Eggs not observed.

\section{Tlacuatzoxyuris sp.}

Host: Tlacuatzin canescens (Allen, 1893).

Host deposition: AMNH165652, Mammalogy.

Locality: Las Tejas: Oaxaca: Mexico $\left(16^{\circ} 21^{\prime} 3.69^{\prime \prime} \mathrm{N}, 95^{\circ}\right.$ 20'3.86"W, $117 \mathrm{~m}$ ), collected August 20, 1950.

Specimens deposited: 1 male AMNH IZC 331457.

Site of Infection: Large intestine.

Male: Small worm, round cephalic vesicle, simple; body width gradually increasing posterior to contracted cephalic vesicle, reaching maximum at midbody, and tapering towards posterior end. Round cephalic plate. Lateral alae run to tip of tail; alae taper at level of cloaca. Length 1023 with both ends truncated, maximum width at midbody 130 . Cephalic vesicle 

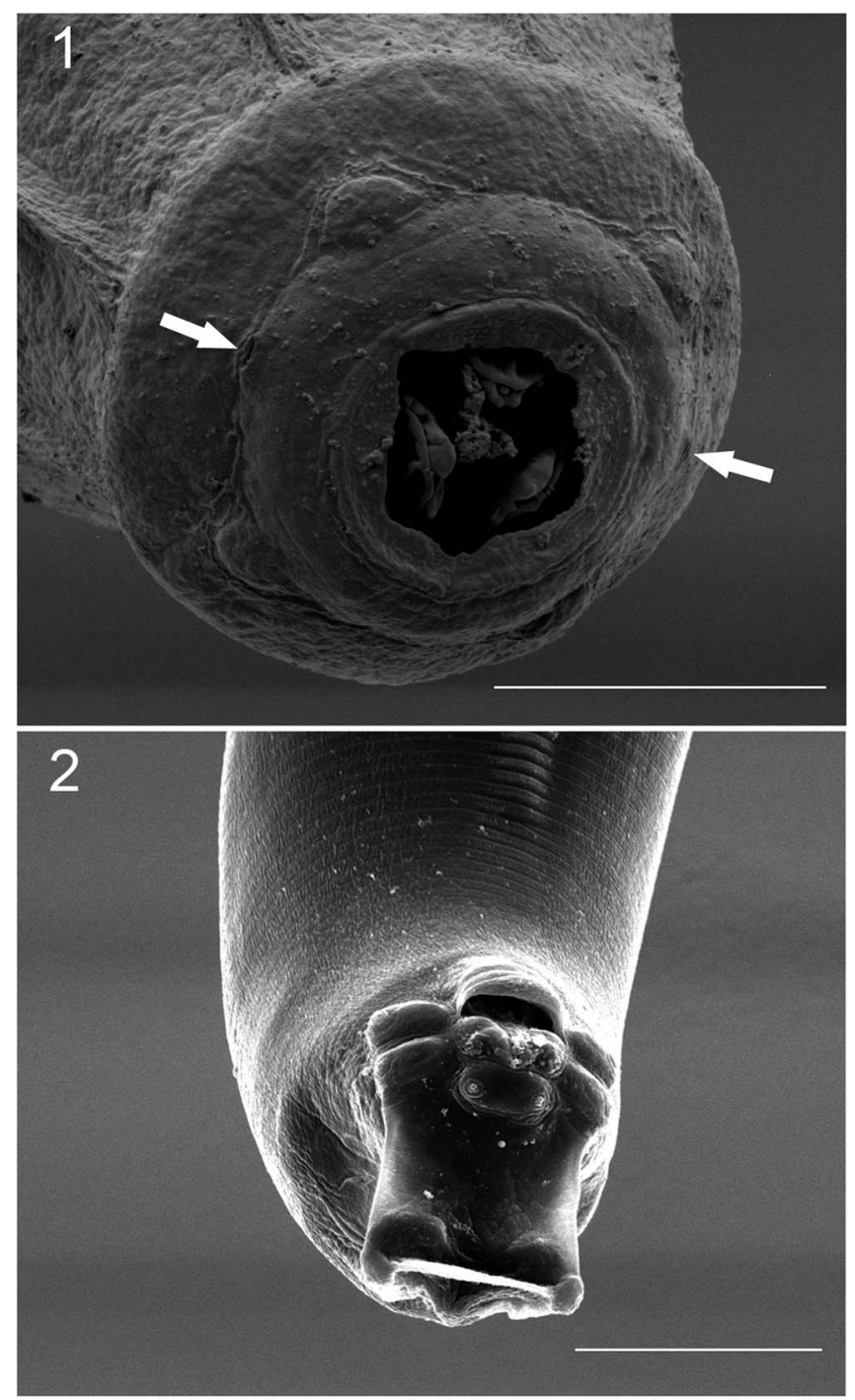

Figures 1, 2. Tlacuatzoxyuris simpsoni n. gen. n. sp., male. (1) cephalic plate showing relative placement of papillae, amphids (white arrows), rim around stoma and teeth; scale bar $=10 \mu \mathrm{m}$. (2) Ventral view of tail, showing paired papillae and postcloacal cuticular ornamentation; scale bar $=25 \mu \mathrm{m}$.

70 long by 48 wide. Alae begin at level of nerve ring and end at level of most posterior mamelon. Esophagus length 179; corpus length 120 , width 29 ; bulb 53 by 48 . Nerve ring, excretory pore and area rugosa located at 89,286 and 228 respectively from anterior end. Continuous ventral area rugosa appears divided into six narrow mamelons. Round postanal region 31 long and 50 wide. Non-salient terminus nine long. Four pairs of genital papillae with pedunculated subterminal pair. Monorchid. Spicule with moderate inflection, length 64. Gubernaculum 44 long.

\section{Discussion}

The genus Tlacuatzoxyuris can be discriminated from other genera present in the northern Neotropics by the absence of an external terminus in the tail of males and a prominent caudal ala. It can be discriminated from Helminthoxys Freitas, Lent and Almeida, 1937, because Tlacuatzoxyuris feature a cephalic vesicle with no prominent cervical alae; from Heteromoxyuris Quentin, 1973 because males feature 5-7 mamelons as ventral ornamentation, and from Passalurus Dujardin, 1845 in that males are endowed with a spicule. Further, the new genus can be discriminated from members of Trypanoxyuris Vevers, 1923 because species in the latter feature complex labial and buccal structures and no ventral mamelons. Finally, the new genus can be discriminated from the five genera of oxyurids present in Australian marsupials (Austroxyuris Johnston \& Mawson, 1938; Adelonema Mawson, 1978; Paraustroxyuris Mawson, 1964; Macropoxyuris Mawson, 1964 and Potoroxyuris Mawson, 1964) in that males included in those taxa have relatively more complex and deep buccal capsules, prominent caudal termini, a caudal ala, and a cuticle with very few mamelons or no ventral ornamentation in males.

Tlacuatzoxyuris simpsoni can be discriminated from all other four species of pinworms infecting mouse and fat-tailed opossums based on the configuration of the stoma and the relatively short spicule and gubernaculum. The stoma of T. simpsoni is separated from the cephalic plate by a terminal rim, it is in a shallow terminal depression and it has the appearance of a very irregular semicircular structure (Figs. 1 and 8). The postcloacal cuticle of males shows ornamentation immediately posterior to the cloaca, just anterior to the pair of submedial papillae (Fig. 2). Finally, both spicule and gubernaculum are relatively short. The eggs of Tlacuatzoxyuris remain unknown.

Tlacuatzoxyuris simpsoni can be differentiated from D. thylamisis based on four main characteristics. First, the relative and absolute size of the spicules and gubernaculum are larger in D. thylamisis than in the homologous structures in T. simpsoni. Second, the cuticle immediately posterior to the cloaca of $T$. simpsoni has ornamentation limited to a small patch between the cloaca and the submedial papillae (Fig. 2), whereas tubercle-like bumps are present on the surface of the cuticle posterior to the submedial papillae of D. thylamisis (Fig. 13). Third, the cephalic vesicle of females of $T$. simpsoni is not very well developed and the cuticle is simple, lacking the characteristic complex reticulated network of vesicles seen in the type specimens of $D$. thylamisis. Finally, the stoma of $T$. simpsoni is subterminal and surrounded by an irregular cuticle (Figs. 1 and 8), whereas the homologous structure appears to be depressed, covered by cuticular flaps and endowed with esophageal teeth in D. thylamisis (see Figs. 1B, C, and 4A, $\mathrm{C}$ in Gardner and Hugot [12].

Tlacuatzoxyuris simpsoni can be readily distinguished from M. dollmeiri in that the latter bears a prominent caudal terminus that emerges from the cuticle, and because the cuticle surrounding the stoma features three lips. The terminus in T. simpsoni is non-salient, a trait shared with the other three monotypic genera. The species described herein features three esophageal teeth, an arrangement that contrasts with the four teeth described in $N$. venusti. In addition, males of the latter species feature up to six pairs of small precloacal papillae. Finally, T. simpsoni can be discriminated from G. agilisis in that the stoma of the latter presents three or more divisions described as lips, as well as a weakly developed cephalic vesicle. 

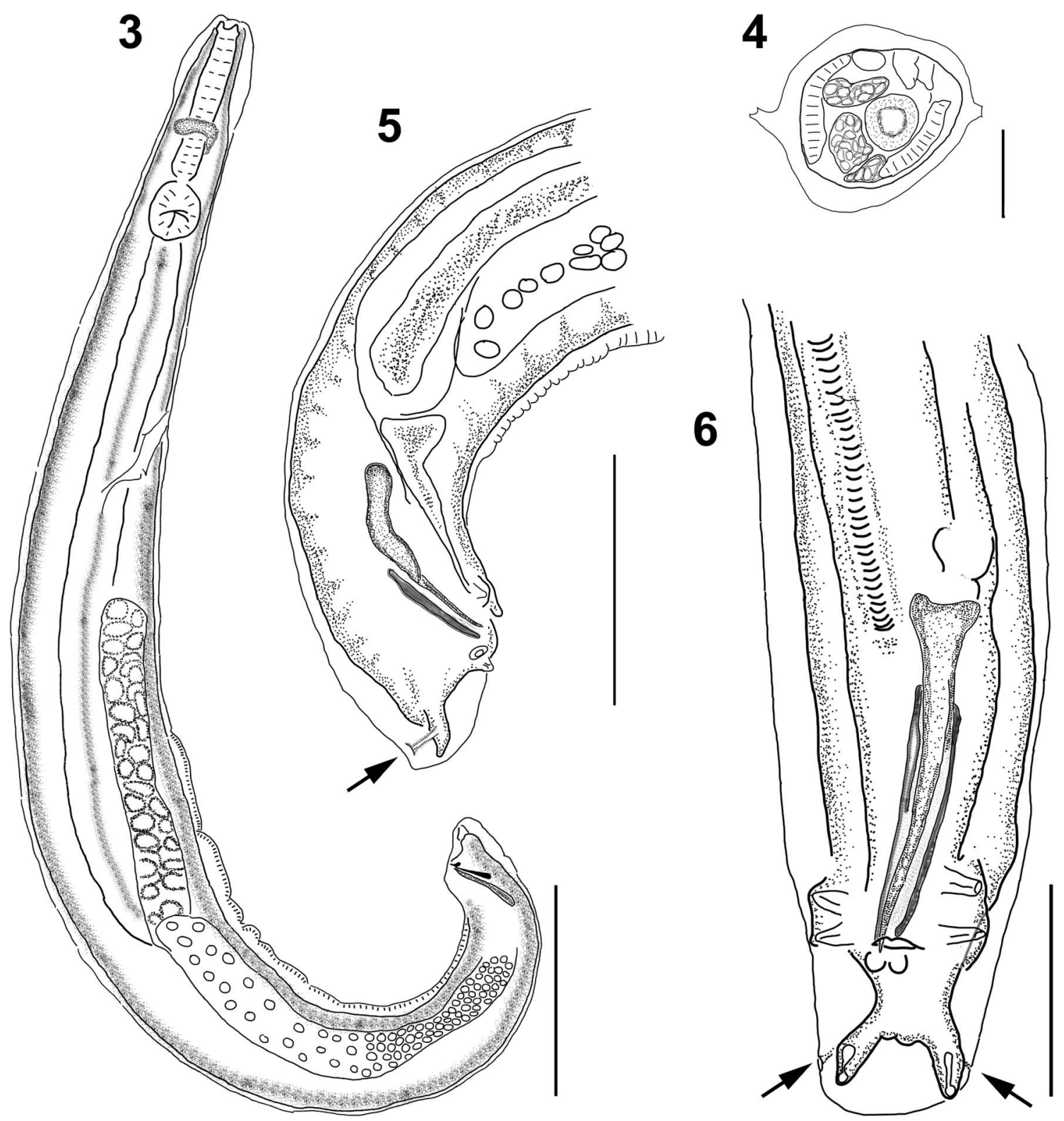

Figures 3-6. Tlacuatzoxyuris simpsoni n. gen. n. sp., male. (3) lateral view of whole body; scale bar $=200 \mu \mathrm{m}$. (4) Cross section at midbody, showing double crested lateral alae; scale bar $=50 \mu \mathrm{m}$. (5) Lateral view of tail, arrow shows phasmid emerging from pedunculated papilla; scale bar $=100 \mu \mathrm{m}$. (6) Ventral view of tail, showing arrangement of papillae; scale bar $=50 \mu \mathrm{m}$.

The divisions around the stoma appear to be cuticular flaps that cover the stoma. These are divided in some of the specimens observed with the aid of SEM [8, 24].

For didelphimorph-dwelling pinworms, the ornamentation of the eggs has been used as an important characteristic to justify the placement of species in monotypic genera. In particular, eggs in Didelphoxyuris are described as non-operculated, whereas the eggs of Gracilioxyuris show three longitudinal ridges with an anterior operculum. This character is of paramount importance in the definition of Gracilioxyuris [8, 24], since both Gracilioxyuris and Didelphoxyuris share similarities on the structure of the cephalic and caudal arrangement of papillae.

No gravid female was collected as a result of our efforts, which yielded a single male from the three screened gray opossums from Tehuantepec and only mature females from the type locality. We predict that the eggs for this species will be operculated as is the case in eggs of M. dollmeiri, $N$. venusti and $G$. agilisis. A taxonomic revision based on a reconstruction of the relationships among the opossum-dwelling pinworms is necessary to clarify homologous characters defining the monotypic genera.

The single specimen collected from Oaxaca likely belongs to a different species, based on the characteristics of the spicules, distance of the area rugosa to anterior end and the shape of the cephalic vesicle. However, the characterization of the species requires a description of character variability of the cephalic plate and vesicle, the arrangement of the caudal papillae and configuration of the structures present in females. Thus, we are unable to present a description at this time. Interestingly, the presence of this second pinworm species mirrors the 

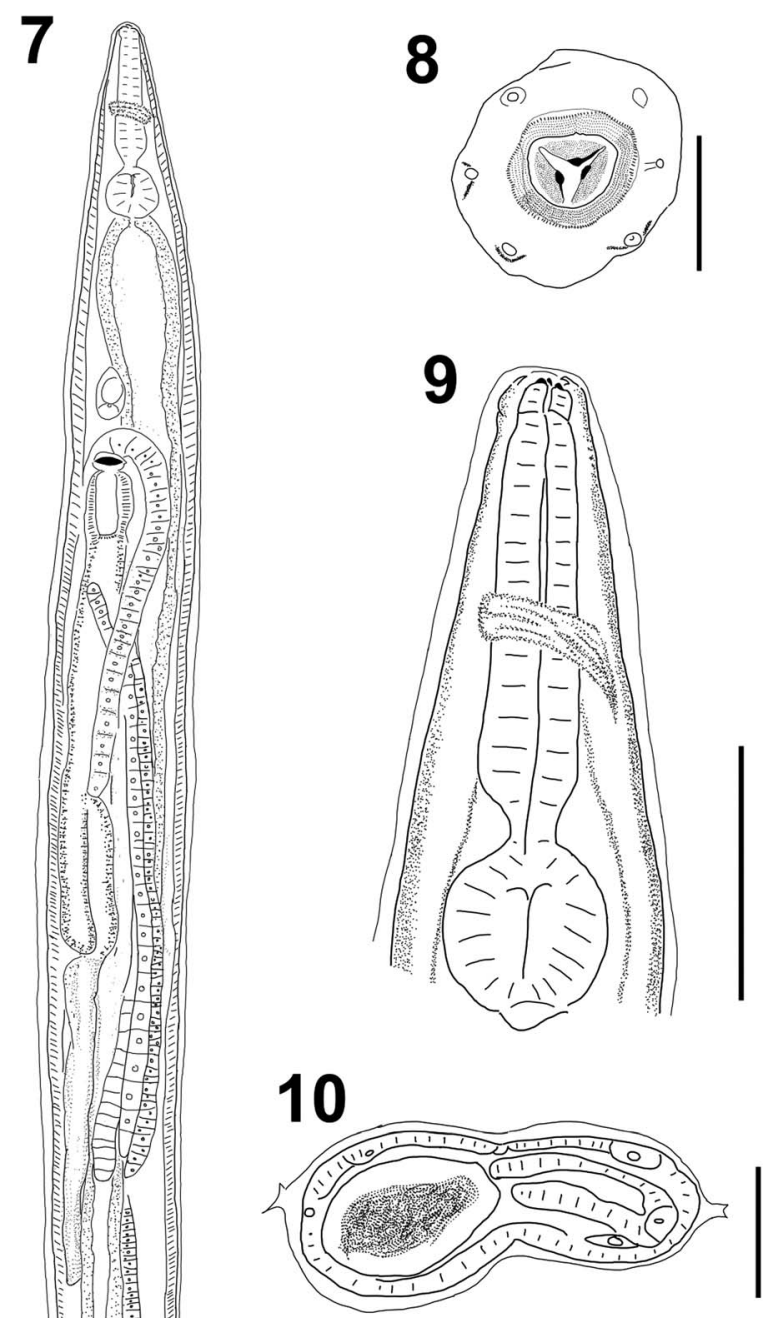

11

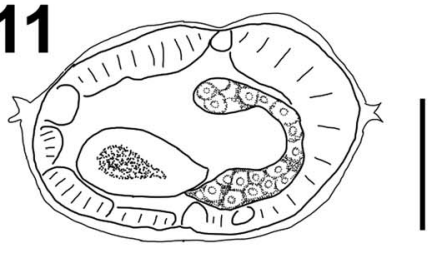

12

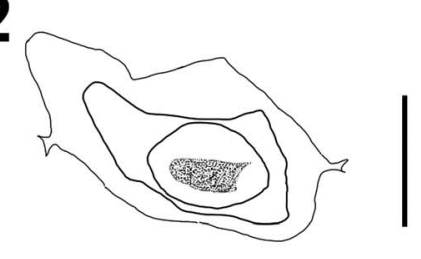

Figures 7-12. Tlacuatzoxyuris simpsoni n. gen. n. sp., female. (7) Ventral view of whole body; scale bar $=300 \mu \mathrm{m}$. (8) Face view, showing teeth and continuous cuticle surrounding stoma; scale bar $=20 \mu \mathrm{m}$. (9) Esophagus, showing relative position of nerve ring, scale bar $=100 \mu \mathrm{m}$. Cross sections at level of (10) vulva, (11) midbody, and (12) slightly anterior to anus; scale bar $=50 \mu \mathrm{m}$.

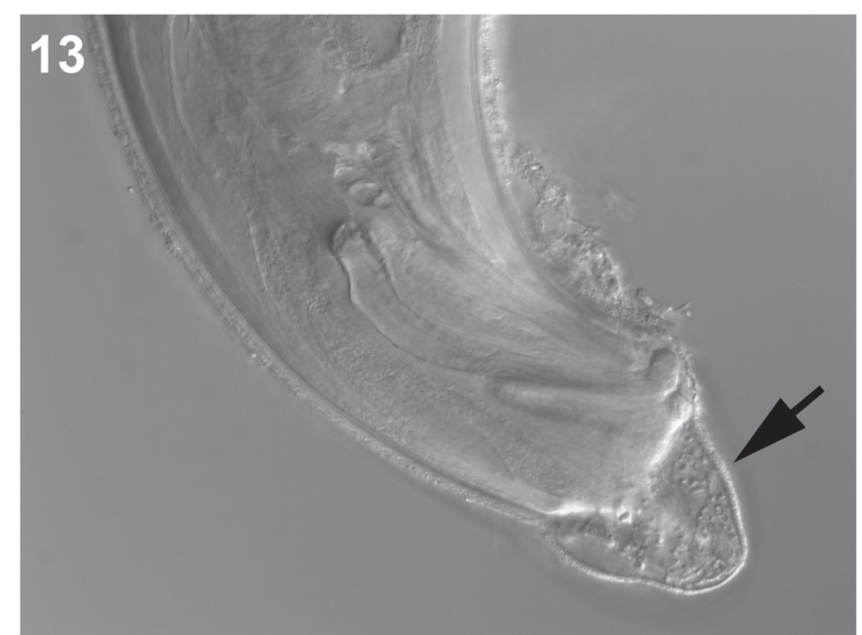

Figure 13. Male, Didelphoxyuris thylamisis, showing extension of postcloacal ornamentation.

splitting of the marsupial host lineage [3]. The pinworms herein documented infected individuals collected from two different clades that represent the geographic clusters of the Balsas basin and the Tehuantepec Isthmus.

Because there is a bias towards the study of common species, we urge colleagues to document the diversity of metazoan parasites associated with all didelphimorph marsupials. The greatest species diversity of didelphimorph marsupials includes small sized opossums, most of which are arboreal or are restricted to small areas in the tropical forests $[4,6]$. We urge the examination of preserved mammalian guts available in scientific collections to continue reconstructing the biological inventory of their symbionts, which includes parasites. In addition, we recommend that scientists working in the field should preserve the parasites or the tissues of freshly caught mammals in the field and link both parasite and host through a relational database [10]. The completion of this parasite inventory will give us an opportunity to better understand the expansion of the marsupials and their pathogens as they were both involved in the Great American Biotic Interchange and may be involved in subsequent events of dispersion or translocation.

Acknowledgements. We thank Luis García and Dr. Gabor Racz, respectively, collection managers of the Colección Nacional de Helmintos (CNHE) and the Harold W. Manter Laboratory of Parasitology (HWML), and Dr. Robert Voss, curator of the Division of Mammalogy of the American Museum of Natural History for allowing the helminthological examination of specimens under his care. Specimens collected in Bolivia were secured through NSF BSR9024816, DEB-9496263 and DBI-0646356, NATO Grant CRG No. 920612. Collaboration was supported by NSF-DUE 1564969 and Programa Integral de Fortalecimiento Institucional of the Universidad Autónoma de Morelos (PIFI-UAEM 2010-2011). Open Access supported by the SIU COPE fund.

\section{Conflict of interest}

The authors declare that they have no conflict of interests. 


\section{References}

1. Alden KJ. 1995. Helminths of the opossum Didelphis virginiana, in southern Illinois, with a compilation of all helminths reported from this host in North America. Journal of the Helminthological Society of Washington, 62(2), 197-208.

2. Amato JFR, Castro PT, Grisi L. 1976. Spirura guianensis (Ortlepp, 1924), parasita de Philander opossum quica (Temminck, 1825) no estado do Rio de Janeiro, Brasil (Nematoda, Spiruridae). Revista Brasileira de Biologia, 36(1), 123-127.

3. Arcangeli J, Light JE, Cervantes FA. 2018. Molecular and morphological evidence of the diversification in the gray mouse opossum, Tlacuatzin canescens (Didelphimorphia), with description of a new species. Journal of Mammalogy, 99(1), 138-158.

4. Astúa D. 2009. Evolution of scapula size and shape in Didelphid marsupials (Didelphimorphia: Didelphidae). Evolution, 63(9), 2438-2456.

5. Brugni N, Flores VR. 2007. Allassogonoporus dromiciops n. sp. (Digenea: Allassogonoporidae) from Dromiciops gliroides (Marsupialia: Microbiotheriidae) in Patagonia, Argentina. Systematic Parasitology, 68(1), 45-48.

6. Cássia-Silva C, Sales LP. 2019. The imprints left by historical contingency on marsupials' life-history traits. Journal of Zoology, 307(2), 149-158.

7. Chabaud AG, Bain O. 1981. Quentius kozeki n. gen., n. sp., Nématode rictulaire parasite d'un Marsupial américain. Annales de Parasitologie Humaine et Comparée, 56(2), 175-178.

8. Feijó IA, Torres EJL, Maldonado A Jr., Lanfredi RM. 2008. A new oxyurid genus and species from Gracilinanus agilis (Marsupialia: Didelphidae) in Brazil. Journal of Parasitology, 94(4), 847-851.

9. Flores-Barroeta L, Hidalgo-Escalante E, Montero-Gei F. 1961. Céstodos de vertebrados. VIII. Revista de Biología Tropical, 9(2), 187-207.

10. Galbreath KE, Hoberg EP, Cook JA, Armién B, Bell KC, Campbell ML, Dunnum JL, Dursahinhan AT, Eckerlin RP, Gardner SL, Greiman SE, Heikki Henttonen F, Jiménez A, Koehler AVA, Nyamsuren B, Tkach VV, Torres-Pérez F, Tsvetkova A, Hope AG. 2019. Building an integrated infrastructure for exploring biodiversity: field collections and archives of mammals and parasites. Journal of Mammalogy, 100(2), 382-393.

11. Gardner AL, Editor. 2007. Mammals of South America. Vol. 1. Chicago, IL: Chicago University Press. p. 669.

12. Gardner SL, Hugot JP. 1995. A new pinworm, Didelphoxyuris thylamisis n. gen., n. sp. (Nematoda: Oxyurida) from Thylamys elegans (Waterhouse, 1839) (Marsupialia: Didelphidae) in Bolivia. Research and Reviews in Parasitology, 55(3), 139-147.

13. Gomes DC, Pinto RM. 1972. Castroia inquassata sp. n., trematódeo de Marmosa sp. (Trematoda, Castroiinae). Atas da Sociedade de Biologia do Rio de Janeiro, 15(3), 129-131.

14. González-Christen A, Rodríguez-Santiago NV. 2014. Primer registro de Tlacuatzin canescens, (Mammalia, Didelphimorphia: Marmosidae) en Veracruz, México. Therya, 5(3), 845-854.

15. Guerrero R, Hugot J-P. 2003. Monodelphoxyuris dollmeiri n. g., n. sp. (Nematoda: Oxyurida) from Monodelphis emiliae in Peru. Systematic Parasitology, 55(1), 73-79.

16. Gutiérrez EE, Jansa SA, Voss RS. 2010. Molecular systematics of mouse opossums (Didelphidae: Marmosa): assessing species limits using mitochondrial DNA sequences, with comments on phylogenetic relationships and biogeography. American Museum Novitates, 3692, 1-22.

17. Guzmán-Cornejo C, Garciá-Prieto L, Acosta-Gutiérrez R, Falcón-Ordaz J, León-Paniagua L. 2012. Metazoarios parásitos de Tlacuatzin canescens y Marmosa mexicana (Mammalia:
Didelphiomorphia) de México. Revista Mexicana de Biodiversidad, 83(2), 557-561.

18. Jiménez FA, Braun JK, Campbell ML, Gardner SL. 2008. Endoparasites of fat-tailed opossums (Thylamys: Didelphidae) from northwestern Argentina and southwestern Bolivia, with the description of a new species of tapeworm. Journal of Parasitology, 94(5), 1098-1102.

19. Monet-Mendoza A, Osorio-Sarabia D, García-Prieto L. 2005. Helminths of the Virginia opossum Didelphis virginiana (Mammalia: Didelphidae) in Mexico. Journal of Parasitology, 91(1), 213-219.

20. Navone GT, Suriano DM. 1992. Pterigodermatites (Paucipectines) spinicaudatis n. sp. (Nematoda: Rictularidae) from Dromiciops australis (Marsupiala: Microbiotheriidae) in Bariloche, Rio Negro, Argentina. Biogeographical distribution and host-parasite relationships. Memórias do Instituto Oswaldo Cruz, 87(4), 533-538.

21. Navone GT, Suriano DM, Pujol CA. 1985. Neohilgertia venusti gen. n. sp. n. (Nematoda: Oxyuridae) from Thylamys venustus cinderellus (Thomas) Reig, Kirsch \& Marshall, 1985 (Marsupialia: Didelphidae) in Burruyacu, Tucuman, ArgentinaSystematic position and possible evolution. Memórias do Instituto Oswaldo Cruz, 85(2), 185-189.

22. Quentin JC. 1973. Présence de Spirura guianensis (Ortlepp, 1924) chez des Marsupiaux néotropicaux. Cycle évolutif. Annales de Parasitologie Humaine et Comparée, 48(1), 117-133.

23. Rossi RV, Voss RS, Lunde DP. 2010. A revision of the didelphid marsupial genus Marmosa Part 1. The species in Tate's "mexicana" and "Mitts" sections and other closely related forms. Bulletin of the American Museum of Natural History, 334(334), 3-83.

24. Santos-Rondon MVS, Pires MP, dos Reis SF, Ueta MT. 2012. Marmosa paraguayana (Marsupialia: Didelphidae) as a new host for Graciloxyurus agilisis (Nematoda: Oxyuridae) in Brazil. Journal of Parasitology, 98, 170-174.

25. Silva MGQE, Costa HMA. 1999. Helminths of white-bellied opossum from Brazil. Journal of Wildlife Diseases, 35(2), 371-374.

26. Sokal RR, Rohlf FJ. 1995. Biometry: The principles and practice of statistics in biological research, 3rd Edn. New York, NY: W. H. Freeman. p. 887.

27. Teta P, D'Elía G, Flores DA, de la Sancha NU. 2009. Diversity and distribution of the mouse opossums of the genus Thylamys (Didelphimorphia, Didelphidae) in northeastern and central Argentina. Gayana, 73(2), 180-199.

28. Voss RS, Emmons LH. 1996. Mammalian diversity in Neotropical lowland rainforests: A preliminary assessment. Bulletin of the American Museum of Natural History, 230, 3-115.

29. Voss RS, Gutierrez EE, Solari S, Rossi RV, Jansa SA. 2014. Phylogenetic relationships of mouse opossums (Didelphidae, Marmosa) with a revised subgeneric classification and notes on sympatric diversity. American Museum Novitates, 3817, 1-27.

30. Voss RS, Jansa SA. 2009. Phylogenetic relationships and classification of didelphid marsupials, and extant radiation of New World metatherian mammals. Bulletin of the American Museum of Natural History, 322, 1-177.

31. Voss RS, Lunde DP, Simmons NB. 2001. The mammals of Paracou, French Guiana: a neotropical lowland rainforest fauna Part 2. Nonvolant species. Bulletin of the American Museum of Natural History, 263, 3-236.

32. Voss RS, Tarifa T, Yensen E. 2004. An introduction to Marmosops (Marsupialia: Didelphidae), with the description of a new species from Bolivia and notes on the taxonomy and distribution of other Bolivian forms. American Museum Novitates, 3466, 1-40. 
Cite this article as: Jiménez FA, Caspeta-Mandujano JM \& Albino-Miranda S. 2019. A new genus and species of pinworm (Nematoda, Oxyuridae) from the gray mouse opossum, Tlacuatzin canescens. Parasite 26, 50.

\section{(0) PARASTE}

An international open-access, peer-reviewed, online journal publishing high quality papers on all aspects of human and animal parasitology

Reviews, articles and short notes may be submitted. Fields include, but are not limited to: general, medical and veterinary parasitology; morphology, including ultrastructure; parasite systematics, including entomology, acarology, helminthology and protistology, and molecular analyses; molecular biology and biochemistry; immunology of parasitic diseases; host-parasite relationships; ecology and life history of parasites; epidemiology; therapeutics; new diagnostic tools.

All papers in Parasite are published in English. Manuscripts should have a broad interest and must not have been published or submitted elsewhere. No limit is imposed on the length of manuscripts.

Parasite (open-access) continues Parasite (print and online editions, 1994-2012) and Annales de Parasitologie Humaine et Comparée (1923-1993) and is the official journal of the Société Française de Parasitologie. 